\title{
In Vitro Rumen Fermentation Characteristics and Fatty Acid Profiles Added with Calcium Soap of Canola/Flaxseed Oil
}

\author{
S. Suharti*, A. R. Nasution, \& K. G. Wiryawan \\ Department of Nutrition and Feed Technology, Faculty of Animal Science, Bogor Agricultural University \\ Jalan Agatis, Kampus IPB Darmaga Bogor 16680, Indonesia \\ (Received 13-10-2017; Reviewed 30-10-2017; Accepted 29-11-2017)
}

\begin{abstract}
This research aimed to assess the effect of adding canola oil and flaxseed oil which were protected with calcium soap (Ca-soap) on the fermentation characteristics, rumen microbial population, and the profile of fatty acids in the rumen during 4 and 8 hours in the in vitro fermentation. The research design used in this study was a completely randomized block design with 3 treatments and 4 replications. The treatments consisted of control ration (Napier grass and concentrate at the ratio of $60: 40$ ), control $+6 \%$ of Ca-soap of canola oil, and control $+6 \%$ of Ca-soap of flaxseed oil. Variables observed were $\mathrm{pH}$ value, $\mathrm{NH}_{3}$ concentration, volatile fatty acid (VFA), dry matter and organic matter digestibility, and fatty acid profile. The results showed that the addition of Ca-soap of canola or flaxseed oil did not affect the $\mathrm{pH}$ value, $\mathrm{NH}_{3}$ concentration, dry matter digestibility, organic matter digestibility, total population of bacteria and protozoa in the rumen. However, the total production of ruminal VFA was increased $(\mathrm{P}<0.05)$ with the addition of Ca soap of canola oil/flaxseed oil. The use of Ca-soap of flaxseed oil increased $(\mathrm{P}<0.05)$ the content of unsaturated fatty acids in the rumen at $4 \mathrm{~h}$ incubation. The addition of Ca-soap of flaxseed oil resulted the lowest $(P<0.05)$ level of unsaturated fatty acids biohydrogenation compared to the other treatments at $4 \mathrm{~h}$ incubation. In conclusion, the addition of Ca soap of canola/flaxseed oil could improve VFA total production. Vegetable oils protected using calcium soap could inhibit unsaturated fatty acid biohidrogenation by rumen microbes. Ca-soap of flaxseed oil could survive from rumen biohydrogenation in the rumen better than Ca-soap of canola oil.
\end{abstract}

Keywords: biohydrogenation, Calcium soap, canola oil, flaxseed oil, rumen fermentation

\section{ABSTRAK}

Penelitian ini bertujuan untuk mengevaluasi pengaruh penambahan minyak canola dan minyak flaxseed yang diproteksi dengan sabun kalsium (Ca-soap) pada karakteristik fermentasi, populasi mikrob rumen, dan profil asam lemak dalam rumen selama 4 dan 8 jam fermentasi in vitro. Rancangan yang digunakan dalam penelitian ini adalah rancangan acak kelompok dengan 3 perlakuan dan 4 ulangan. Perlakuan terdiri atas: kontrol (rumput gajah:konsentrat= 60:40), kontrol + sabun kalsium minyak canola $6 \%$, dan kontrol + sabun kalsium minyak flaxseed $6 \%$. Hasil penelitian menunjukkan bahwa penambahan sabun kalsium minyak kanola atau flaxseed tidak mempengaruhi nilai $\mathrm{pH}$, konsentrasi $\mathrm{NH}_{3}$, kecernaan bahan kering, kecernaan bahan organik, jumlah populasi bakteri dan protozoa di rumen, namun meningkatkan $(P<0,05)$ produksi VFA total. Pada inkubasi 4 jam, penambahan sabun kalsium minyak flaxseed nyata meningkatkan $(P \leq 0,05)$ kandungan asam lemak tak jenuh dalam rumen. Penggunaan sabun kalsium flaxseed oil menghasilkan level biohidrogenasi terendah pada 4 jam inkubasi. Dapat disimpulkan bahwa minyak nabati yang diproteksi dengan menggunakan sabun kalsium dapat meningkatkan fermentasi rumen dan menghambat secara parsial proses biohidrogenasi asam lemak tak jenuh oleh mikrob rumen. Asam lemak tidak jenuh dari sabun kalsium minyak flaxseed dapat bertahan terhadap biohidrogenasi rumen lebih baik dibandingkan sabun kalsium minyak kanola.

Kata kunci: biohidrogenasi, minyak flaxseed, minyak kanola, sabun kalsium

${ }^{*}$ Corresponding author:

E-mail: harti_ss@yahoo.com 


\section{INTRODUCTION}

Meat product from ruminant contains high saturated fatty acids due to the biohydrogenation process by rumen microbe that convert unsaturated fatty acids from the diet into saturated fatty acids (Lourenço et al., 2010). Therefore, one of strategies to improve the unsaturated fatty acids content of ruminant meat was the addition of unsaturated fatty acids sources from vegetable oil.

However, the content of saturated fatty acids of red meat is high and some of consumers do not want it. Saturated fat intake is a risk factor for coronary heart disease, especially lauric acid, myristic acid, palmitic acid, and stearic acid are associated with an increased risk of coronary heart disease (Zong et al., 2016). Almeida et al. (2006) stated that beef meat had proportion of saturated fatty acids about $53.3 \pm 2.12 \%$ and polyunsaturated fatty acids about $3.0 \pm 0.5 \%$. However, according to Gadeyne et al. (2015), the content of unsaturated fatty acids in ruminant feed will decrease due to biohydrogenation processes in the rumen. The unsaturated fatty acid will be changed to saturated fatty acids and then the cis and trans isomers will be accumulated. According to Jenkins et al. (2008), fatty acid that enters the rumen would experience the lipolysis process and would be occured hydrolysis of fats caused by lipase enzyme. The release of free fatty acids will be followed by the process of biohydrogenation, namely reduction of the amount of double bond carbon chains of fatty acids.

High fat content in the diet can be used as an alternative energy needed by cattle. However, according to Bunting (1996), feeding fat sources that are too high (> $5 \%$ of total diet) in ruminant can reduce microbial populations and disrupt the microbial activity to digest the fiber. Vafa et al. (2009) stated that the addition of canola oil, fish oil, and combination of canola oil and fish oil (50:50) significantly decreased in vitro dry matter digestibility (IVDMD) and in vitro organic matter digestibility (IVOMD) of alfalfa hay and corn silage. The decline in IVDMD and IVODM was also linearly correlated with increasing levels of oil (2\%-6\%).

The biohydrogenation process of unsaturated fatty acids into saturated fatty acids in the rumen can be reduced by protecting the unsaturated fatty acids sources of feed with calcium soaps method. Calcium soap is a product of fat saponification with alkaline, and the addition of mineral calcium (Ca) in order to change the oil into a solid form. According to Mosley et al. (2002), the source of fatty acids that are protected can reduce biohydrogenation process of linoleic acid (C18: 2), so that the levels of linoleic acid (C18: 2) in the abomasum keep high. According to Jenkins (1993), to prevent the process of biohydrogenation on providing fat source more than $5 \%$, the fat (especially saturated fat) should be protected with calcium soaps. Alexander et al. (2002) said that the addition of Ca soap of sunflower oil with $10 \%$ DM in the sheep diet (in vivo) did not affect the digestibility of fiber.

Vegetable oil that can be used to improve the content of unsaturated fatty acids in meat are canola oil and flaxseed oil. According to Carter (1993), flaxseed con- tains $32 \%-45 \%$ of oil, which is $51 \%-55 \%$ alpha - linolenic acid (Omega 3), 15\%-18\% linoleic (Omega 6). According to Holländer et al. (2012), canola oil contains $60 \%$ of oleic acid, $20 \%$ of linoleic acid, and $10 \%$ of linolenic acid. Hidayah et al. (2014) stated that Ca soap of flaxseed oil and Ca soap of canola oil have a higher resistance against biohydrogenation process in the rumen than the sesame oil, based on fatty acid measurements on the 4th hour incubation. Biohydrogenation of Ca soap of flaxseed oil and Ca soap of canola oil decrease by $50 \%$ and $27.11 \%$, while sesame oil calcium soaps experienced biohydrogenation entirely. This research aimed to assess the effect of adding Ca soap of canola oil and Ca soap of flaxseed at the level of $6 \%$ in the cattle diet on the in vitro characteristics of rumen fermentation, total bacterial and protozoa population, and the fatty acid profile at the 4 th hour and 8th hour fermentation.

\section{MATERIALS AND METHODS}

\section{Diet and Nutrient Composition of Feed}

The diet was composed of $60 \%$ forage (napier grass) and $40 \%$ concentrate (Table 1 ). The diet were formulated for cattle at the fattening phase with protein requirement $(\mathrm{CP})$ of at least $11.69 \%$ and energy (TDN) of at least $66.15 \%$ (Kearl 1982). The treatment in this research was control/T0 (without the addition of $\mathrm{Ca}$ soaps), $\mathrm{T} 1$ (control $+6 \%$ Ca soap of canola oil), and T2 (control $+6 \%$ Ca soap of flaxseed oil).

\section{Preparation of Calcium Soap of Vegetable Oils}

The canola oil and flaxseed oil were produced by Golden Bridge (Malaysia), and Green Tosca Pte,Ltd (Singapore), respectively. Preparation of calcium soap used method by Jenkin \& Palmquist (1984). The vegetable oils were heated on a hotplate $\left(200^{\circ} \mathrm{C}\right)$ and added a solution of $\mathrm{NaOH}$. The mixture was homogenized with rotation speed of $800 \mathrm{rpm}$ until the fat completely dissolved. Then it was re-heated and added a solution of $\mathrm{CaCl}_{2}$ (2.35 $\mathrm{g} \mathrm{CaCl} 2$ and $4.7 \mathrm{~mL}$ of aquadest). After the addition of $\mathrm{CaCl}_{2}$ solution, cooling was done until it forms calcium soap solids.

Table 1. Nutrient composition of diet (dry matter bassis) with $60 \%$ napier grass and $40 \%$ concentrate

\begin{tabular}{lrrr}
\hline \multirow{2}{*}{ Nutrient (\%) } & \multicolumn{3}{c}{ Treatments } \\
\cline { 2 - 4 } \multicolumn{1}{c}{ Try matter (DM) } & \multicolumn{1}{c}{ T0 } & \multicolumn{1}{c}{ T2 } \\
\hline Ash & 5.49 & 51.04 & 81.04 \\
Crude protein & 13.55 & 14.5 & 5.78 \\
Crude fat & 4.96 & 10.02 & 14.44 \\
Crude fibre & 14.10 & 14.99 & 14.93 \\
TDN & 72.39 & 72.37 & 72.53 \\
\hline
\end{tabular}

Note: $\mathrm{T} 0=$ control $(60 \%$ napier grass $+0 \%$ concentrate $), \mathrm{T} 1=$ control $+6 \%$ Ca soap of canola oil, $\mathrm{T} 2=\mathrm{con}$ trol $+6 \%$ Ca soap of flaxseed oil. ${ }^{*}$ by calculation. 


\section{In Vitro Fermentation}

In vitro fermentation used the method by Tilley \& Terry (1963) which was modified with the amount of substrate was $600 \mathrm{mg}$. Each treatment diet was added to the fermenter tube as much as $600 \mathrm{mg}$. Then, $40 \mathrm{~mL}$ of Mc Dougall solution and $10 \mathrm{~mL}$ of rumen fluid were added and incubated at shaker water bath at $39^{\circ} \mathrm{C}$.

The rumen fluid for this experiment was collected $3 \mathrm{~h}$ after morning feeding from the 3 rumen-fistulated Ongole crossbred beef cattles with Ethical Approval from Animal Care and Use Committee (AUAC) 01$2013 \mathrm{~b}$ IPB. After $4 \mathrm{~h}$ of incubation, samples were taken for the measurements of $\mathrm{pH}$ value, total volatile fatty acid (VFA), ammonia $\left(\mathrm{NH}_{3}\right)$, microbes population, and sample of fatty acid at 4 th $\mathrm{h}$ incubation, then continued incubation of 8 hours for sampling fatty acids at 8 th $\mathrm{h}$. Samples of dry matter digestibility (DMD) and organic matter digestibility (OMD) were taken after fermentation for $48 \mathrm{~h}$.

\section{Sampling and Measurement}

The $\mathrm{pH}$ values of the samples fermented at $4^{\text {th }}$ hours were measured by using a $\mathrm{pH}$ meter. Ammonia $\left(\mathrm{NH}_{3}\right)$ concentration was measured using microdiffusion Conway method and total VFA contents were determined by steam distillation method (AOAC, 1990). The measurements of dry matter digestibility (DMD) and organic matter digestibility (OMD) used methods of Tilley \& Terry (1963).

The measurement of the total population of bacteria and protozoa was done using method based on Ogimoto \& Imai (1981). The numbers of protozoa in the rumen fluid were counted under a microscope according to Ogimoto \& Imai (1981). The $0.5 \mathrm{~mL}$ of rumen fluid was mixed with $0.5 \mathrm{~mL}$ of Trypan Blue Formalin Saline (TBFS) consisted of $100 \mathrm{~mL}$ of $35 \%$ formaldehide, $2 \mathrm{~g}$ of trypan blue, $8 \mathrm{~g}$ of $\mathrm{NaCl}$, and $900 \mathrm{~mL}$ of destilled water and diluted 5 times. The population of protozoa was counted directly on 5 divisions by using a counting chamber $\left(0.1 \mathrm{~mm} \times 1 \mathrm{~mm}^{2}\right)$ under a microscope (40x) and calculated by the following formula: $\mathrm{P}=(\mathrm{n} / 5) \times 10^{4}$ $\mathrm{xd}$, where $\mathrm{P}=$ number of ciliates per $1 \mathrm{~mL}$ of rumen contents, $\mathrm{n}=$ number of division that counted in the counting chamber, $\mathrm{d}=$ dilution factor of the sample.

Population of total bacteria were counted according to Ogimoto \& Imai (1981) by using roller tube method and Rumen-Fluid Glucose Cellobiose Agar (RGCA) Modification. The RGCA solution consist of $15 \mathrm{~mL}$ of mineral solution I, $15 \mathrm{~mL}$ of mineral solution II, $0.1 \mathrm{~mL}$ of $0.1 \%$ Resazurin solution, $40 \mathrm{~mL}$ of distilled water, 2 $\mathrm{g}$ of bacto agar, $30 \mathrm{~mL}$ of rumen fluid, $0.2 \mathrm{~g}$ of glucose, $0.2 \mathrm{~g}$ of cellobiose, $0.1 \mathrm{~g}$ of cysteine. $\mathrm{HCl} . \mathrm{H}_{2} \mathrm{O}, 1 \mathrm{~mL}$ of $8 \% \mathrm{Na}_{2} \mathrm{CO}_{3}$ solution, $1 \mathrm{~g}$ of bacto casiton, $0.3 \mathrm{~g}$ of yeast extract, $0.2 \mathrm{~g}$ of yeast extract, $0.2 \mathrm{~g}$ of starch soluble, 0.4 $\mathrm{g}$ of $\mathrm{NaHCO}_{3}$ and $1 \mathrm{~mL}$ of sodium lactate. Forty-five $\mathrm{mL}$ of anerobic dilution solution and $0.5 \mathrm{~mL}$ of rumen sample were placed in the hungate tube. The sample was diluted until 10 times dilution. The $0.5 \mathrm{~mL}$ of samples from dilution 6 to 10 were placed into petri dish that contained RGCA media, then rotated to form a figure eight in order to hold the sample mixed homogeneously. Samples were incubated for $48 \mathrm{~h}$ at a temperature of $37-40^{\circ} \mathrm{C}$. The calculation of the bacterial population by using the following formula: $\mathrm{BP}=\mathrm{C} \times 10^{\mathrm{n}} \times 2$, which is $\mathrm{BP}=$ bacterial population, $\mathrm{C}=$ number of colony forming unit, $\mathrm{n}=$ number of dilution.

Fatty acid profiles were measured by using the method of Carriquiry et al. (2008) that was using Gas Chromatography which had a column containing teknokroma TR-CN (100). Type of Gas Chromatography used was GC 2010, Shimadzu Corp., Kyoto, Japan. Before sample injection to the GC, fatty acid extraction from rumen liquid was carried out by dissolving in a mixture of hexane and isopropanol solvents with the ratio of 3: 2 (Corl et al., 2001).

\section{Data Analysis}

The data were analyzed by using Analysis of Variance (ANOVA) and any significant difference among treatments would be further tested by Duncan test using statistical software SPSS 16. The level of biohydrogenation was calculated by subtracting the unsaturated fatty acid concentration at the incubation 0 hour with the unsaturated fatty acid concentration at 4 or $8 \mathrm{~h}$ after incubation and multiplied by $100 \%$.

\section{RESULTS}

\section{Rumen Fermentation Characteristic and Microbial Populations}

The protozoal and bacterial population in the rumen were similar among treatments. However, the addition of Ca-soap of canola or flaxseed oil increased $(\mathrm{P} \leq 0.05)$ total VFA production compared to the control (Table 2).

Table 2. Fermentation characteristics and microbe population in rumen with the addition of Ca soap canola oil and Ca soap flaxseed oil

\begin{tabular}{lrrr}
\hline \multirow{2}{*}{ Variables } & \multicolumn{3}{c}{ Treatments } \\
\cline { 2 - 4 } & \multicolumn{1}{c}{ T0 } & T1 & \multicolumn{1}{c}{ T2 } \\
\hline $\mathrm{pH}$ & $6.90 \pm 0.15$ & $7.00 \pm 0.25$ & $7.00 \pm 0.25$ \\
Total VFA (mM) & $120.38 \pm 5.62^{\mathrm{a}}$ & $147.77 \pm 9.80^{\mathrm{b}}$ & $160.73 \pm 15.00^{\mathrm{b}}$ \\
$\mathrm{NH}_{3}(\mathrm{mM})$ & $11.81 \pm 3.24$ & $11.47 \pm 1.57$ & $10.79 \pm 2.13$ \\
$\mathrm{DMD}(\%)$ & $69.59 \pm 6.93$ & $70.16 \pm 6.53$ & $67.35 \pm 2.02$ \\
OMD (\%) & $81.48 \pm 10.05$ & $79.44 \pm 9.14$ & $75.71 \pm 2.70$ \\
$\begin{array}{l}\text { Total bacteria } \\
\text { (Log cfu/ mL) }\end{array}$ & $6.68 \pm 0.76$ & $6.27 \pm 0.25$ & $6.27 \pm 0.18$ \\
$\begin{array}{l}\text { Protozoa }(\mathrm{Log} \\
\text { cell/mL) }\end{array}$ & $3.95 \pm 0.13$ & $3.85 \pm 0.26$ & $3.94 \pm 0.13$ \\
\hline
\end{tabular}

Note: Means in the same row with different superscripts differ significantly $(\mathrm{P}<0.05) . \mathrm{T} 0=$ control $(60 \%$ napier grass $+0 \%$ concentrate $)$ $\mathrm{T} 1=$ control $+6 \%$ of Ca soap of canola oil, $\mathrm{T} 2=$ control $+6 \%$ of $\mathrm{Ca}$ soap of flaxseed oil. 
Fatty Acid Profile and Biohydrogenation Level of Unsaturated Fatty Acids at 4 and 8 Hours Fermentation

At the $4 \mathrm{~h}$ of in vitro incubation, the addition of $\mathrm{Ca}$ soap flaxseed oil significantly $(\mathrm{P} \leq 0.05)$ increased the number of unsaturated fatty acids in the rumen (Table 3). However, in the percentage unit, fatty acid profiles were similar among treatments (Table 4).
The addition of Ca soap of flaxseed oil resulted the lowest $(\mathrm{P} \leq 0.05)$ level of unsaturated fatty biohydrogenation compared to other treatments in the $4 \mathrm{~h}$ incubation. In contrast, at $8 \mathrm{~h}$ incubation, the level of unsaturated fatty acid biohydrogenation were similar among treatments (Table 5).

Table 3. Fatty acid profile at of 0,4 , and 8 hours fermentation

\begin{tabular}{|c|c|c|c|c|c|c|c|c|c|}
\hline \multirow{3}{*}{$\begin{array}{l}\text { Fatty acids } \\
(\mathrm{mg} / 50 \mathrm{~mL})\end{array}$} & \multicolumn{9}{|c|}{ Treatments } \\
\hline & \multicolumn{3}{|c|}{ T0 } & \multicolumn{3}{|c|}{$\mathrm{T} 1$} & \multicolumn{3}{|c|}{$\mathrm{T} 2$} \\
\hline & 0 hour & 4 hour & 8 hour & 0 hour & 4 hour & 8 hour & 0 hour & 4 hour & 8 hour \\
\hline Saturated fatty acid & 0.029 & $0.76 \pm 0.27$ & $0.53 \pm 0.07$ & 0.030 & $0.39 \pm 0.14$ & $0.54 \pm 0.27$ & 0.019 & $0.48 \pm 0.17$ & $0.51 \pm 0.24$ \\
\hline SCFA & 0.000 & 0.13 & 0.11 & 0.000 & 0.07 & 0.06 & 0.000 & 0.03 & 0.07 \\
\hline Butyric (C4) & 0.000 & 0.00 & 0.11 & 0.000 & 0.07 & 0.06 & 0.000 & 0.03 & 0.07 \\
\hline MCFA & 0.015 & 0.21 & 0.14 & 0.015 & 0.13 & 0.17 & 0.009 & 0.12 & 0.14 \\
\hline Caproic (C6) & 0.000 & 0.00 & 0.00 & 0.000 & 0.00 & 0.00 & 0.000 & 0.00 & 0.00 \\
\hline Caprilyc (C8) & 0.001 & 0.01 & 0.00 & 0.001 & 0.01 & 0.00 & 0.001 & 0.00 & 0.00 \\
\hline Capric (C10) & 0.002 & 0.01 & 0.01 & 0.002 & 0.01 & 0.01 & 0.001 & 0.01 & 0.01 \\
\hline Lauric (C12) & 0.012 & 0.19 & 0.13 & 0.012 & 0.11 & 0.16 & 0.008 & 0.11 & 0.13 \\
\hline LCFA & 0.208 & 0.53 & 0.35 & 0.500 & 0.30 & 0.39 & 0.365 & 0.51 & 0.44 \\
\hline Myristic (C14) & 0.004 & 0.10 & 0.06 & 0.004 & 0.04 & 0.06 & 0.003 & 0.05 & 0.06 \\
\hline Palmitic (C16:0) & 0.008 & 0.21 & 0.14 & 0.009 & 0.10 & 0.13 & 0.005 & 0.19 & 0.14 \\
\hline Stearic (C18:8) & 0.001 & 0.12 & 0.09 & 0.002 & 0.06 & 0.12 & 0.002 & 0.09 & 0.11 \\
\hline Unsaturated fatty acid & 0.194 & $0.10 \pm 0.03^{b}$ & $0.07 \pm 0.05$ & 0.484 & $0.10 \pm 0.02^{b}$ & $0.08 \pm 0.06$ & 0.355 & $0.18 \pm 0.05^{a}$ & $0.08 \pm 0.05$ \\
\hline LCFA & 0.194 & 0.10 & 0.07 & 0.484 & 0.10 & 0.08 & 0.355 & 0.18 & 0.08 \\
\hline Oleic (C18:1) & 0.083 & 0.08 & 0.05 & 0.279 & 0.07 & 0.07 & 0.189 & 0.13 & 0.06 \\
\hline Linoleic (C18:2) & 0.111 & 0.02 & 0.01 & 0.195 & 0.03 & 0.01 & 0.163 & 0.05 & 0.02 \\
\hline Linolenic (C18:3) & 0.000 & 0.00 & 0.00 & 0.100 & 0.00 & 0.00 & 0.004 & 0.00 & 0.00 \\
\hline
\end{tabular}

Note: Means in the same row with different superscripts differ significantly $(\mathrm{P}<0.05)$. T0 $=$ control $(60 \%$ napier grass $+0 \%$ concentrate $), \mathrm{T} 1=$ control $+6 \%$ of Ca soap of canola oil, $\mathrm{T} 2=$ control $+6 \%$ of Ca soap of flaxseed oil.

Table 4. Percentage of fatty acid profile at 0,4 , and 8 hours fermentation

\begin{tabular}{|c|c|c|c|c|c|c|c|c|c|}
\hline \multirow{3}{*}{ Fatty acids (\%) } & \multicolumn{9}{|c|}{ Traetments } \\
\hline & \multicolumn{3}{|c|}{ T0 } & \multicolumn{3}{|c|}{$\mathrm{T} 1$} & \multicolumn{3}{|c|}{$\mathrm{T} 2$} \\
\hline & 0 hour & 4 hour & 8 hour & 0 hour & 4 hour & 8 hour & 0 hour & 4 hour & 8 hour \\
\hline Saturated fatty acid & 12.84 & $87.74 \pm 6.14$ & $91.89 \pm 9.25$ & 5.91 & $77.62 \pm 10.51$ & $87.75 \pm 4.93$ & 5.14 & $70.79 \pm 11.38$ & $86.43 \pm 4.82$ \\
\hline SCFA & 0.00 & 11.95 & 17.99 & 0.00 & 12.28 & 7.57 & 0.00 & 3.92 & 7.81 \\
\hline Butyric (C4) & 0.00 & 11.95 & 17.99 & 0.00 & 12.28 & 7.57 & 0.00 & 3.92 & 7.81 \\
\hline MCFA & 6.76 & 25.02 & 24.51 & 2.87 & 24.65 & 33.62 & 2.53 & 17.01 & 24.2 \\
\hline Caproic (C6) & 0.08 & 0.00 & 0.00 & 0.03 & 0.00 & 0.00 & 0.03 & 0.00 & 0.00 \\
\hline Caprilyc (C8) & 0.48 & 0.47 & 0.29 & 0.20 & 0.90 & 0.41 & 0.18 & 0.44 & 0.19 \\
\hline Capric (C10) & 0.73 & 1.66 & 1.49 & 0.30 & 2.29 & 1.31 & 0.27 & 1.69 & 1.61 \\
\hline Lauric (C12) & 5.46 & 22.88 & 22.73 & 2.33 & 21.47 & 31.91 & 2.05 & 14.88 & 22.4 \\
\hline LCFA & 93.24 & 63.03 & 57.50 & 97.13 & 63.07 & 58.81 & 97.47 & 79.07 & 67.99 \\
\hline Myristic (C14) & 1.99 & 11.73 & 10.24 & 0.86 & 7.51 & 12.25 & 0.75 & 7.11 & 10.41 \\
\hline Palmitic (C16:0) & 3.50 & 24.73 & 24.29 & 1.81 & 20.94 & 18.63 & 1.38 & 30.58 & 24.78 \\
\hline Stearic (C18:8) & 0.59 & 14.31 & 14.86 & 0.37 & 12.24 & 15.68 & 0.48 & 12.34 & 19.23 \\
\hline Unsaturated fatty acid & 87.16 & $12.26 \pm 6.14$ & $8.11 \pm 9.25$ & 94.09 & $22.38 \pm 10.51$ & $12.25 \pm 4.93$ & 94.86 & $29.03 \pm 11.38$ & $13.57 \pm 4.82$ \\
\hline LCFA & 87.16 & 12.26 & 8.11 & 94.09 & 22.38 & 12.25 & 94.86 & 29.03 & 13.57 \\
\hline Oleic (C18:1) & 37.14 & 9.63 & 5.99 & 54.16 & 15.97 & 10.33 & 50.38 & 21.21 & 11.29 \\
\hline Linoleic (C18:2) & 50.02 & 2.63 & 2.12 & 37.95 & 6.45 & 1.92 & 43.41 & 7.84 & 2.29 \\
\hline Linolenic (C18:3) & 0.00 & 0.00 & 0.00 & 1.98 & 0.00 & 0.00 & 1.07 & 0.00 & 0.00 \\
\hline
\end{tabular}

Note: $\mathrm{T} 0=$ control $(60 \%$ napier grass $+0 \%$ concentrate $), \mathrm{T} 1=$ control $+6 \%$ of Ca soap of canola oil, $\mathrm{T} 2=\mathrm{control}+6 \%$ of $\mathrm{Ca}$ soap of flaxseed oil. 
Table 5. Biohydrogenation level of unsaturated fatty acids at $4^{\text {th }}$ and $8^{\text {th }}$ hour incubation

\begin{tabular}{ccc}
\hline \multirow{2}{*}{ Treatments } & \multicolumn{2}{c}{ The level of biohyrogenation (\%) } \\
\cline { 2 - 3 } & 4 h incubation & $8 \mathrm{~h}$ incubation \\
\hline T0 & $51.10 \pm 13.62^{\mathrm{b}}$ & $90.99 \pm 12.74$ \\
T1 & $79.35 \pm 3.72^{\mathrm{a}}$ & $82.79 \pm 12.91$ \\
T2 & $48.89 \pm 12.79^{\mathrm{b}}$ & $77.96 \pm 13.88$ \\
\hline
\end{tabular}

Note: Means in the same column with different superscripts differ significantly $(\mathrm{P}<0.05)$. $\mathrm{T} 0=$ control $(60 \%$ napier grass $+0 \%$ concentrate), $\mathrm{T} 1=$ control $+6 \%$ of Ca soap of canola oil, $\mathrm{T} 2=\mathrm{control}+6 \%$ of Ca soap of flaxseed oil.

\section{DISCUSSION}

Rumen $\mathrm{pH}$ value remained within the normal range and the process of feed degradability in the rumen was not hamper with the used of Ca soap of canola/flaxseed oil. The addition of Ca soap of canola/ flaxseed oil at the level of $6 \%$ did not alter dry matter and organic matter digestibility in the rumen. The ammonia concentration also similar among treatments. It showed that the addition of Ca soap of canola/flaxseed oil at the level of $6 \%$ did not affect the ammonia-forming microbes. This result indicates that the addition of plant oil protected by calcium soap did not interfere rumen microbe and their activities in the feed degradation and fermentation. Moreover, Adeyemi et al. (2015) stated that the addition of $8 \%$ BCPO (a blend of canola oil $80 \%$ and $20 \%$ palm oil) did not interfere $\mathrm{NH}_{3}-\mathrm{N}$ and rumen $\mathrm{pH}$, but significantly reduced the total VFA, acetate, butyrate, acetate/propinat ratio, and methane produce.

The total VFA production significantly improved with the addition of Ca soap of canola/flaxseed oil compared to the control treatment. The low value of total VFA in controls is linear with the low of total bacterial population. According to Hidayah et al. (2014), supplementation of calcium soaps of flaxseed oil has the highest value of total VFA production. This result indicates that protection of canola or flaxseed oil by using calcium soaps technology can stimulate total VFA production by rumen microbe. One of the possible reasons for the increased VFA production in the present study might be due to glycerol content in the canola/flaxseed oil since not all fatty acids could be protected by calcium soap. Some proportions of fatty acid still could be degraded by rumen bacteria to produce glycerol. According to $\mathrm{Li}$ et al. (2009), total VFA concentration can be increased by administration of linolenic acid, malic-linolenic acid, and fumaric-linolenic acid with increasing incubation time.

At $4 \mathrm{~h}$ fermentation, biohydrogenation level of the used of Ca soap of canola oil was higher than that of $\mathrm{Ca}$ soap of flaxseed oil. This result is presumably because canola oil contains higher oleic acid (C18: 1) and linoleic acid (C18: 2). In addition, the bond between fatty acids and $\mathrm{NaOH}$ is not perfect and can not protect unsaturated fatty acids from biohydrogenation processes by rumen bacteria. Barletta et al. (2016) stated that protected sources of soybean grain (SG) and calcium salts of un- saturated fatty acids (CS) promoted a greater abomasal flow of linoleic acid (C18:2) and lower biohydrogenation rate compared to the soybean oil (SO) diet.

The increased content of unsaturated fatty acids in the rumen with the addition of Ca soap of flaxseed oil can be caused by the bond between calcium soaps and fat is fairly strong, so Ca soap of flaxseed oil will have lower biohydrogenation. The content of high linolenic acid (C18:3) causes Ca soaps of flaxseed oil have lower biohydrogenation on the 4 hours of fermentation when compared to Ca soap of canola oil, which is rich in oleic acid. Linolenic acid is a long-chain fatty acid which has a low melting point, so that the bond of carbon chains of flaxseed oil is not easy to be broken at the 4 hours fermentation. According to Wood et al. (2003), long-chain fatty acids have lower melting points and this condition will affect the process of oxidation and saturation reactions in the rumen.

Linolenic acid (C18: 3) undergo a process of biohydrogenation longer than oleic acid (C18: 1) and linoleic acid (C18: 2) because it has a higher number of double bonds. The higher the number of double bonds, the more difficult the chain bonding to be split up, thus causing Ca soaps have better capacities to protect oleic (C18: 1) and linoleic (C18: 2) acids in flaxseed oil than in canola oil, that contains a slightly higher linolenic acid. According to Hidayah et al. (2014), the types of oil which are most resistant to the biohydrogenation process, respectively, were sesame oil, flaxseed oil, and canola oil. According to Fincham et al. (2014), linoleic and linolenic acids are precursors of essential fatty acids in fattening cattle feed, but biohydrogenation of linoleic and linolenic acids will produce fatty acids of trans-10 and trans-11 18: 1. Lake et al. (2014) suggested that the increased concentration of C18: 1 trans-11 in adipose tissue of lactating cows with feeding source of oleic safflower seed can increase the content of cis-9, trans11CLA in the body tissue at $10.84 \%$ compared to the control diet $(34.44 \%)$ and feed sources of linoleic safflower seed increased by $6.43 \%$.

Canola oil and flaxseed oil contain a higher long chain polyunsaturated fatty acids (LCPUFA). However, due to the biohydrogenation process in the rumen, the long chain polyunsaturated fatty acids will experience saturation reaction. Medium chain fatty acid (MCFA) and short chain fatty acid (SCFA) at 8 hours fermentation was increased due to the reduction of double bond carbon chains. However, the flow rate of saturation reaction does not occur as a whole due to the protection of calcium soaps. According to Eun et al. (2008), the addition of fish oil (3\%) into steer diet can increase the flow rate of trans-11 C18: 1 and the change of trans C18: 1 to C18: 0 that would decrease by $39 \%$ compared to the control diet. Supplementation of concentrates with fish oil will increase LCPUFA which will inhibit the growth of bacteria that is capable of saturating C18: 3, C18: 2, and C18: 0.

Biohydrogenation level of unsaturated fatty in the $4 \mathrm{~h}$ and $8 \mathrm{~h}$ incubations have different patterns. The highest biohydrogenation level was reached by Ca soap of canola oil treatment in the $4 \mathrm{~h}$ incubation, but in the $8 \mathrm{~h}$ incubation it was reached by control treatment. 
The used of Ca soap of flaxseed oil resulted the lowest biohydrogenation level both in the $4 \mathrm{~h}$ and $8 \mathrm{~h}$ incubations. These results indicated that in the long term $(8 \mathrm{~h}$ incubation), flaxseed oil coated by calcium soap technology could protect the unsaturated fatty acid of the oil from rumen microbe biohydrogentaion. In the form of calcium soap of flaxseed oil, the flaxseed oil will inert in rumen with $\mathrm{pH} 7$ and rumen bacteria could not degrade it. Hidayah et al. (2014) said that biohydrogenation of Ca soap of flaxseed oil and Ca soap of canola oil decreased by $50 \%$ and $27.11 \%$, while sesame oil calcium soaps were completely biohydrogenated.

\section{CONCLUSION}

The addition of $\mathrm{Ca}$ soaps of canola/flaxseed oil at a level of $6 \%$ did not affect the $\mathrm{pH}$ value, $\mathrm{NH}_{3}$ concentration, dry matter digestibility (DMD) and organic matter digestibility (OMD), total population of protozoa and bacteria in the rumen. The addition of Ca soap of canola/flaxseed oil could improve VFA total production. Vegetable oils protected by using calcium soap could inhibit unsaturated fatty acid biohidrogenation by rumen microbes. Ca soap of flaxseed oil could survive from rumen biohydrogenation in the rumen better than Ca soap of canola oil.

\section{ACKNOWLEDGEMENT}

This research was funded by Ministry of Research, Technology and Higher Education through "IPB Fundamental Research Grant".

\section{REFERENCES}

Adeyemi, K. D., A. Q. Sazili, M. Ebrahimi, A. A. Samsudin, A. R. Alimon, R. Karim, S. A. Karsani, \& A. B. Sabow. 2015. Effects of blend of canola oil and palm oil on nutrient intake and digestibility, growth performance, rumen fermentation and fatty acids in goats. J. Anim. Sci. 87: 11371147. https://doi.org/10.1111/asj.12549

Alexander, G., Z. P. Rao, \& J. R, Prasad. 2002. Effect of supplementing sheep with sunflower acid oil or its calcium soap on nutrient utilization. Asian-Australas. J. Anim. Sci. 15: 1288-1293.

Almeida, J. C., M. S. Perassolo, J. L. Camargo, N. Bragagnolo, \& J. L. Gross. 2006. Fatty acid composition and cholesterol content of beef and chicken meat in Southern Brazil. Brazilian Journal of Pharmaceutical Sciences. 42: 109-117. https://doi.org/10.1590/S1516-93322006000100012

AOAC. 1990. Official Methods of Analysis. $12^{\text {th }}$ Ed. Association of Official Analytical Chemistry, Washington DC Washington.

Barletta, R. V., J. R. Gandra, V. P. Betero, C. E. Araujoa, T. A. Del Valle, G. F. de Almeida, E. Ferreira de Jesus, R. D. Mingoti, B. C. Benevento, J. E. de Freitas Junior, \& F. P. Rennóa. 2016. Ruminal biohydrogenation and abomasal flow of fatty acids in lactating cows: oilseed provides ruminal protection for fatty acids. Anim. Feed Sci. Technol. 219: 111-121. https://doi.org/10.1016/j.anifeedsci.2016.06.011

Boadi, D., C. Benchaar, J. Chiquette, \& D. Massé. 2004. Mitigation strategies to reduce enteric methane emissions from dairy cows: Update review. Can. J. Anim. Sci. 84: 319-335. https://doi.org/10.4141/A03-109

Bunting, L.D., J. M. Fernandez, R. J. Fornea, T.W. White, M. A.
Froetschel, J. D. Stone, \& K. Ingawa. 1996. Seasonal effects of supplemental fat or undegradable protein on the growth and metabolism of Holstein calves. J. Dairy Sci. 79: 16111620. https://doi.org/10.3168/jds.S0022-0302(96)76524-4

Carriquiry, M., W. J. Weber, L.H. Baumgard, \& B. A. Crooker. 2008. In-vitro biohydrogenation of four dietary fats. Anim. Feed Sci. Technol. 141: 339-355. https://doi.org/10.1016/j. anifeedsci.2007.06.028

Carter, J. 1993. Flaxseed as a source of alpha linolenic acid. J. Am Coll Nutr. 12: 551. https://doi.org/10.1080/07315724.1 993.10718352

Corl, A., L. H. Baumgard, D.A. Dwyer, J. M. Griinari, B. S. Phillips \& D. E. Bauman. 2001. The role of $\Delta-9$ desaturase in the production of cis-9, trans-11 CLA. J. Nutr Biochem. 12: 622-630. https://doi.org/10.1016/S0955-2863(01)00180-2

Eun, J. K., S. A. Huws, M. R. F. Lee, J. D. Wood, S. M. Muetzel, R. J. Wallace, \& N. D. Scollan. 2008. Fish oil increases the duodenal flow of long chain polyunsaturated fatty acids and trans-11 18:1 and decreases 18:0 in steers via changes in the rumen bacterial community. J. Nutr. 138:889-96.

Fincham, J. R., J. P. Fontenot, W. S. Swecker, J. H. Herbein, J. P. S. Neel, G. Scaglia, W. M. Clapham, \& D. R. Notter. 2014. Fatty acid metabolism and deposition in subcutaneous adipose tissue of pasture- and feedlot-finished cattle. J. Anim Sci. 87:3259-3277. https://doi.org/10.2527/jas.2008-1277

Gadeyne, F., G. Van Ranst, B. Vlaeminck, E. Vossen, P. Van der Meeren \& V. Fievez. 2015. Protection of polyunsaturated oils against ruminal biohydrogenation and oxidation during storage using a polyphenol oxidase containing extract from red clover. J. Food Chem. 171: 241-250. https:// doi.org/10.1016/j.foodchem.2014.08.109

Jenkins, T.C. \& D.L. Palmquist .1984. Effect of fatty acid or calcium soap on rumen and total nutrient digestibility of dairy ration. J. Dairy Sci. 67:978. https://doi.org/10.3168/ jds.S0022-0302(84)81396-X

Jenkins, T. C., R. J. Wallace, P. J. Moate, \& E. E. Mosley. 2008. BOARD-INVITED REVIEW: Recent advances in biohydrogenation of unsaturated fatty acids within the rumen microbial ecosystem. J. Anim Sci. 86:397-412. https://doi. org/10.2527/jas.2007-0588

Jenkins, T.C. 1993. Lipid metabolism in the rumen. J. Dairy Sci. 76: 3851-3863. https://doi.org/10.3168/jds. S0022-0302(93)77727-9

Hidayah, N., S. Suharti, \& K.G. Wiryawan. 2014. In vitro rumen fermentation of ration supplemented with protected vegetable oils. Med. Pet. 37: 129-135. https://doi.org/10.5398/ medpet.2014.37.2.129

Holländer, U.T., N. A. Michael Eskin, \& M. Bertrand. 2012. Canola and Rapeseed Production, Processing, Food Quality, and Nutrition. London (UK): CRC Press.

Kearl, L.C. 1982. Nutrient Requirements of Ruminants in Developing Countries. Logan Utah (USA): International feedstuffs Institiute Utah Agricultural Experiment Station Utah State University.

Lake, S. L., E. J. Scholljegerdes, T. R. Weston, D. C. Rule, \& B.W. Hess. 2014. Postpartum supplemental fat, but not maternal body condition score at parturition, affects plasma and adipose tissue fatty acid profiles of suckling beef calves. J Anim Sci. 84:1811-1819. https://doi.org/10.2527/ jas.2005-619

Lourenço, M., E. Ramos-Morales, \& R. J. Wallace. 2010. The role of microbes in rumen lipolysis and biohydrogenation and their manipulation. Animal 4:1008-1023. https://doi. org/10.1017/S175173111000042X

Li, X.Z., S. H. Choi, G. L .Jin, C.G. Yan, R. J. Long, C.Y. Liang, \& M. K. Song. 2009. Linolenic acid in association with malate or fumarate increased CLA production and reduced methane generation by rumen microbes. Asian-Aust. J Anim. Sci. 22: 819-826. 
Mosley, E. E., G. L. Powell, M. B. Riley, \& T. C. Jenkins. 2002. Microbial biohydrogenation of oleic acid to trans isomers in vitro. J. Lipid Res. 43:290-296.

Ogimoto, K. \& S. Imai. 1981. Atlas of Rumen Microbiology. Japan Scientific Societes, Tokyo.

Tilley, J.M.A. \& R.A. Terry. 1963. A two stage technique for in vitro digestin offorage crops. J. Bri Grass Soc. 18: 108-111. https://doi.org/10.1111/j.1365-2494.1963.tb00335.x

Vafa, T. S., A.A Naserian, A.R. Heravi, R. Valizadeh, \& M.D. Mesgaran. 2009. Effects of different levels of fish oil and canola oil on in vitro dry matter and organis matter digestibility. Res. J. Biol. Sci. 4: 1171 - 1174.
Wood, J. D., R. I. Richardson, G. R. Nute, A.V. Fisher, M. M. Campo, E. Kasapidou, P.R. Sheard, \& M. Enser. 2003. Effects of fatty acids on meat quality. Meat Sci. 66: 21-32. https://doi.org/10.1016/S0309-1740(03)00022-6

Zong, G., Y. Li, A. J. Wanders, M. Alssema, P. L. Zock, W. C. Willett, F. B. Hu, \& Q. Sun. 2016. Intake of individual saturated fatty acids and risk of coronary heart disease in US men and women: two prospective longitudinal cohort studies. British Med. J. BMJ 2016;355:i5796. https://doi. org/10.1136/bmj.i5796 